\title{
The impact of date palm fruits and their component polyphenols, on gut microbial ecology, bacterial metabolites and colon cancer cell proliferation
}

\author{
Noura Eid, Sumia Enani, Gemma Walton, Giulia Corona, Adele Costabile, Glenn Gibson, Ian Rowland \\ and Jeremy P. E. Spencer* \\ Department of Food and Nutritional Sciences, School of Chemistry, Food and Pharmacy, University of Reading, Reading RG6 6 AP, UK \\ (Received 27 January 2014 - Final revision received 29 January 2014 - Accepted 2 April 2014)
}

Journal of Nutritional Science (2014), vol. 3, e46, page 1 of 9

doi:10.1017/jns.2014.16

Abstract

The fruit of the date palm (Phoenix dactylifera L.) is a rich source of dietary fibre and polyphenols. We have investigated gut bacterial changes induced by the whole date fruit extract (digested date extract; DDE) and its polyphenol-rich extract (date polyphenol extract; DPE) using faecal, pH-controlled, mixed batch cultures mimicking the distal part of the human large intestine, and utilising an array of microbial group-specific 16S rRNA oligonucleotide probes. Fluorescence microscopic enumeration indicated that there was a significant increase in the growth of bifidobacteria in response to both treatments, whilst whole dates also increased bacteroides at $24 \mathrm{~h}$ and the total bacterial counts at later fermentation time points when compared with DPE alone. Bacterial metabolism of whole date fruit led to the production of SCFA, with acetate significantly increasing following bacterial incubation with DDE. In addition, the production of flavonoid aglycones (myricetin, luteolin, quercetin and apigenin) and the anthocyanidin petunidin in less than $1 \mathrm{~h}$ was also observed. Lastly, the potential of DDE, DPE and metabolites to inhibit Caco-2 cell growth was investigated, indicating that both were capable of potentially acting as antiproliferative agents in vitro, following a $48 \mathrm{~h}$ exposure. This potential to inhibit growth was reduced following fermentation. Together these data suggest that consumption of date fruits may enhance colon health by increasing beneficial bacterial growth and inhibiting the proliferation of colon cancer cells. This is an early suggestion that date intake by humans may aid in the maintenance of bowel health and even the reduction of colorectal cancer development.

Key words: Date palm fruit: Date polyphenols: Gut ecology: Colonic cancer inhibition

The human colon harbours about $10^{13}$ micro-organisms and over 1000 species of bacteria and is considered the most metabolically active site in the human body ${ }^{(1)}$. These intestinal microbiota have been shown to play a prominent role in maintaining gut health and affecting the aetiology and pathogenesis of a wide range of disease and disorders, including inflammatory bowel disease, diarrhoea and colorectal cancer ${ }^{(2)}$. Identifying dietary regimens and components that can beneficially modify the gut microbiota represents a possible strategy for reducing the risk of the development of such diseases ${ }^{(3)}$. Much research in this regard has focused on 'prebiotics', and in particular the ability of certain types of dietary fibre, especially indigestible oligosaccharides, to stimulate the growth of and/or activity of beneficial gut bacteria such as bifidobacteria and lactobacilli leading to a concomitant positive effect on colonic health $^{(3,4)}$. Recent work has focused on prebiotics and other fibre-rich foods that may be fermented by the lower gut, and insoluble compounds ${ }^{(5-11)}$ and polyphenols ${ }^{(12-17)}$ that modify the gut ecology and increase beneficial types of bacteria. Indeed, a large number of human intervention studies have indicated that foods rich in fibres ${ }^{(18-25)}$ and polyphenols ${ }^{(26-28)}$ and/or rich in both compounds ${ }^{(29)}$ have an impact on the gut microbiota, including cocoa ${ }^{(26)}$, pomegranate ${ }^{(14)}$, wine $^{(28)}$, blueberries ${ }^{(27)}$, whole-grain cereal $^{(18)}$, maize-derived whole grain ${ }^{(22)}$, artichoke ${ }^{(19,20)}$ and apples ${ }^{(29)}$. The effects of such foods are likely to be dependent on both the dietary

Abbreviations: DDE, digested date extract; DPE, date polyphenol extract; FISH, fluorescence in situ hybridisation; FOS, fructo-oligosaccharide; SRB, sulforhodamine B.

* Corresponding author: Professor Jeremy Spencer, fax +44 118931 0080, email j.p.e.spencer@reading.ac.uk 
fibres and polyphenols that they contain, and it has been suggested that such foods may be an effective strategy for the maintenance of a beneficial gut microbial ecology, leading to better gastrointestinal health ${ }^{(30)}$.

Date fruit (Phoenix dactylifera L.) contains high levels of both dietary fibre and polyphenols. Although an important food in the Middle East and North Africa, dates are also cultivated and consumed to an increasing degree in some parts of the USA, in particular Southern California, Arizona and Texas ${ }^{(31)}$. Dates are rich in energy and carbohydrates, mainly fructose, glucose and sucrose, which are absorbed in the upper gut, but also contain relatively high amounts of dietary fibres $(6 \cdot 4-11.5 \%)$. The latter exist mainly as insoluble fibre with smaller amounts of soluble fibre ${ }^{(32)}$. Previously, we have shown that dates also contain significant amounts of polyphenols including phenolic acids (gallic, protocatechuic, hydroxybenzoic, vanillic, isovanillic, syringic, caffeic, ferulic, sinapic, p-coumaric, isoferulic), flavonoid glycosides (quercetin, luteolin, apigenin and kaempferol) and anthocyanidins ${ }^{(33)}$. Furthermore, polyphenol levels were observed to vary depending on cultivar type and degree of ripening: kimri (unripe), khalal (full-size, crunchy), rutab (ripe, soft) and the final tamr stage (ripe, reduced moisture) ${ }^{(34)}$. The Ajwa variety of date, a common cultivar grown in Saudi Arabia, has been observed previously to exhibit antiinflammatory and antioxidant potentials ${ }^{(35)}$. In our previous work, Ajwa dates were considered to be the richest in polyphenols, specifically anthocyanidins, in comparison with other varieties, such as Barni and Khalas; however, polyphenols content reduce dramatically at the last stage of ripening ${ }^{(33)}$. As well as investigating the impact of the whole date fruit on gut microbiology, the present study aimed to assess the potential of these polyphenols to exert effects on the gut microbiota. Polyphenols are usually poorly absorbed from the small intestine and hence reach the colon where they are subject to extensive biodegradation by the resident microbiota ${ }^{(36,37)}$, although the effects of this metabolism on the growth of the microbiota is less well understood. Furthermore, date polyphenols and their metabolites, generated by interaction with the gut bacteria, may also favour the colonic epithelium, via their potential to inhibit proliferation of human colon cancer cells. The present study was designed to assess the impact of whole date fruit and date polyphenol extracts (DPE) on the faecal microbiota, using $\mathrm{pH}$-controlled, mixed faecal batch cultures. In addition, bacterial metabolites, such as SCFA and phenolic metabolites, were also measured. The secondary aim was to assess the potential of both whole date and DPE to inhibit colon cancer cell growth using Caco-2 cells.

\section{Materials and methods}

\section{Collection of dates}

Ajwa date fruit were harvested at the tamr stage from Al-Gudaibi farm (Al-Qaseem, Saudi Arabia) 1 week before transportation to the UK. Date fruits were transported to the UK in polyethylene boxes at $4^{\circ} \mathrm{C}$. Samples were then stored at $-20^{\circ} \mathrm{C}$ before extraction and digestion.

\section{Preparation of extracts}

Date polyphenol extracts. Dates $(100 \mathrm{~g})$ were pitted, weighed and homogenised in $300 \mathrm{ml}$ methanol-water (4:1; v/v) containing $10 \% \mathrm{NaF}(1 \mathrm{M})$ to inhibit polyphenol oxidase ${ }^{(31)}$. Extracts were stirred for $2 \mathrm{~h}$ at $20^{\circ} \mathrm{C}$ and then filtered through a sintered funnel (porosity $=1$ ) to remove solids. Aqueous methanol extracts were concentrated under vacuum using a rotator vacuum evaporator (ORME Scientific Ltd) and the remaining residue was diluted in acidified water $(\mathrm{pH}$ 2; $\mathrm{HCl})$. Sugars were removed by adding $3 \mathrm{~g}$ of the extract to a XAD-16 resin packed column $(50 \mathrm{~cm}$ length $\mathrm{x} 2 \cdot 2 \mathrm{~cm}$ diameter) (Sigma Aldrich) ${ }^{(38)}$. Elution of sugars was achieved by the addition of $100 \mathrm{ml}$ of acidified water ( $\mathrm{pH} \mathrm{2;} \mathrm{HCl),}$ followed by $300 \mathrm{ml}$ of distilled water at a constant rate $(0.5 \mathrm{ml} / \mathrm{min})$ using a diaphragm-metering pump (STEPDOS; Scientific Laboratory Suppliers). The Fehling test was carried out to ascertain the presence of sugars in the water extracts ${ }^{(39)}$. Following removal of all sugars, elution of phenolics was achieved by the addition of $400 \mathrm{ml}$ of methanol at a flow rate of $0.5 \mathrm{ml} / \mathrm{min}$. The eluent collected was concentrated using a rotator vacuum evaporator at $40^{\circ} \mathrm{C}$ and the concentrated extract stored at $-80^{\circ} \mathrm{C}$ until analysis. The $100 \mathrm{~g}$ of dates contained $1500 \mathrm{mg}$ of polyphenols by weight. The polyphenol profile has been characterised in prior experiments, which was published in our previous study ${ }^{(33)}$.

Digested date extracts. Date fruits were pitted and $60 \mathrm{~g}$ of sample were added to $150 \mathrm{ml}$ distilled water and mixed in a stomacher for $2 \mathrm{~min}$. The solution was then mixed with $\alpha$-amylase $(20 \mathrm{mg})$ in $\mathrm{CaCl}_{2}(1 \mathrm{~mm} ; 6.25 \mathrm{ml})$ and incubated at $37^{\circ} \mathrm{C}$ for $30 \mathrm{~min}$ on a shaker, which is called the oral digestion phase. In the following gastric phase of digestion, pepsin $(2.7 \mathrm{~g})$ was dissolved in $\mathrm{HCl}(0.1 \mathrm{M} ; 25 \mathrm{ml})$ and then the mixed sample was added. The $\mathrm{pH}$ was adjusted to 2 using $\mathrm{HCl}(6 \mathrm{M})$ and incubated at $37^{\circ} \mathrm{C}$ for $2 \mathrm{~h}$ on a shaker. The last digestion was the small-intestinal phase where pancreatin $(560 \mathrm{mg})$ and bile $(3.5 \mathrm{~g})$ were dissolved in $\mathrm{NaHCO}_{3}(125 \mathrm{ml})$ and the sample added. $\mathrm{pH}$ was adjusted to 7 using $\mathrm{NaOH}(6 \mathrm{M})$ and incubated at $37^{\circ} \mathrm{C}$ for $3 \mathrm{~h}$ on a shaker. Samples were transferred to cellulose dialysis membranes (1 kDa molecular weight), purchased from Cheshire Biotech, to be dialysed against $\mathrm{NaCl}\left(0.01 \mathrm{~m} ; 5^{\circ} \mathrm{C}\right)$ to remove low-molecular mass digestion products. After $15 \mathrm{~h}$, the dialysis fluid was changed and dialysis continued for an additional $2 \mathrm{~h}$. Afterwards, samples were freeze dried (5 d) and were ready to be used in in vitro fermentation. All chemicals were purchased from Sigma Aldrich.

\section{Faecal sample preparation}

Faecal samples were obtained from three healthy volunteers, who had not consumed any antibiotics for at least 6 months before the study and had no history of gastrointestinal disease. Volunteers were not regular consumers of probiotic/prebiotic supplements. Samples were prepared on the day of the experiment and within $1 \mathrm{~h}$ of production were diluted $(1: 10, \mathrm{w} / \mathrm{v})$ in 
an anaerobic phosphate buffer (0.1 $\mathrm{m} ; \mathrm{pH} 7 \cdot 4)$. Faecal samples were then homogenised in a stomacher for $2 \mathrm{~min}$, then sieved, forming faecal slurries from each volunteer used in three different batch culture experiments.

\section{Preparation of fermentation vessels}

Basal nutrient medium was prepared before the experiment, by adding peptone water $(2 \mathrm{~g} / \mathrm{l})$, yeast extract $(2 \mathrm{~g} / \mathrm{l}), \mathrm{NaCl}$ $(0 \cdot 1 \mathrm{~g} / \mathrm{l}), \mathrm{K}_{2} \mathrm{HPO}_{4}(0.04 \mathrm{~g} / \mathrm{l}), \mathrm{KH}_{2} \mathrm{PO}_{4}(0.04 \mathrm{~g} / \mathrm{l}), \mathrm{NaHCO}_{3}$ $(2 \mathrm{~g} / \mathrm{l}), \mathrm{MgSO}_{4} \cdot 7 \mathrm{H}_{2} \mathrm{O} \quad(0.01 \mathrm{~g} / \mathrm{l}), \mathrm{CaCl}_{2} \cdot 6 \mathrm{H}_{2} \mathrm{O} \quad(0.01 \mathrm{~g} / \mathrm{l})$, Tween $80(2 \mathrm{ml} / \mathrm{l})$, haemin $(50 \mathrm{mg} / \mathrm{l})$, vitamin $\mathrm{K}_{1}(10 \mathrm{ml} / \mathrm{l})$, L-cysteine $(0.5 \mathrm{~g} / \mathrm{l})$, bile salts $(0.5 \mathrm{~g} / \mathrm{l})$, resazurin $(1 \mathrm{mg} / \mathrm{l})$ and distilled water. The autoclaved medium was aseptically added to the batch-culture vessels. Vessels were sparged overnight with $\mathrm{O}_{2}$-free $\mathrm{N}_{2}$ at a rate of $15 \mathrm{ml} / \mathrm{min}$. Before inoculation, $\mathrm{pH}$ of the medium was adjusted to $6 \cdot 8$, using both basic $(1 \mathrm{M}-\mathrm{NaOH})$ and acidic $(1 \mathrm{M}-\mathrm{HCl})$ solutions, which were monitored and modulated by a $\mathrm{pH}$ controller.

\section{Inoculation of substrate in the batch culture}

At the start of the experiment, $15 \mathrm{ml}$ of faecal slurry $(1: 10, \mathrm{w} / \mathrm{v})$ and substrates were added to each batch-culture vessel. The first experiment consisted of three vessels: (1), containing the DPE $(1.5 \mathrm{~g}$ of date fruit contained $150 \mathrm{mg} / \mathrm{ml}$ of polyphenols and other small molecular weight components extracted by XAD-column chromatography; these are expected to reach the human colon); (2), fructo-oligosaccharide (FOS) (1 \%, w/v, $1.5 \mathrm{~g}$ Raftilose P95) purchased from Orafti $(1 \%, \mathrm{w} / \mathrm{v})$; and (3), a control vessel (without a substrate). For the second experiment, three vessels were run: (1), containing digested date extract (DDE) (1.5 g, containing polyphenols and dietary fibres); (2), FOS (1\%, w/v, $1.5 \mathrm{~g}$ Raftilose P95); and (3), a control vessel (without a substrate). The concentrations chosen in this experiment reflect the amounts that would reach the colon after consumption ( $1.5 \mathrm{~g}$ containing $150 \mathrm{mg}$ of polyphenols in the culture model is approximately equivalent to $100 \mathrm{~g}$ of dates giving $1500 \mathrm{mg} / 1500 \mathrm{ml}$, which is consuming about seven to ten pieces of date fruit). Both experiments (batch cultures were carried out in triplicates) were run under anaerobic conditions for $48 \mathrm{~h}$ and $7 \mathrm{ml}$ of sample collected at five time points $(0,5$, 10,24 and $48 \mathrm{~h}$ ) analysed for bacterial count using fluorescence in situ hybridisation (FISH) analysis, metabolites using HPLC and cancer cell inhibition using the sulforhodamine B (SRB) assay.

\section{Bacterial enumeration using fluorescence in situ hybridisation}

This method has been described by Daims et al. ${ }^{(40)}$ where fermented samples were prepared, fixed and hybridised to be ready for counting. Batch-cultured samples were removed at different time points $(0,5,10$ and $24 \mathrm{~h})$ and suspended to concentrate the bacterial cells. Fixation took place by adding the batch cultures in $4 \%(\mathrm{w} / \mathrm{v})$ paraformaldehyde. Samples were incubated for 3 to $12 \mathrm{~h}$ at $4^{\circ} \mathrm{C}$ without freezing, and then centrifuged at $15000 \mathrm{~g}$ for $5 \mathrm{~min}$ to remove residual paraformaldehyde. Cells were resuspended in PBS-ethanol and stored at $-20^{\circ} \mathrm{C}$ until FISH analysis. For FISH analysis, samples were diluted with PBS/SDS (sodium dodecyl sulphate) diluents and applied to six-well slides for hybridisation. Dilutions were chosen, according to the each fluorescentlabelled 16S rRNA-targeted oligonucleotide probe. These probes are labelled with the fluorescent dye $\mathrm{Cy} 3$ to enumerate bacterial cells in samples. FISH analysis was conducted using six different probes: Bif164 for Bifidobacterium ${ }^{(41)}$; Lab158 for Lactobacillus-Enterococcus ${ }^{(42)}$; ATO for Atopobium-Coriobacterium group $^{(43)}$; Erec482 for Clostridium coccoides-Eubacterium rectale ${ }^{(44)}$; Chis150 for Clostridium subgrp. histolyticum ${ }^{(45)}$; Bac303 for Bacteroides-Prevotella ${ }^{(42)}$; and EUB338 for total bacteria ${ }^{(46)}$. Then $20 \mu$ of the diluted samples were added to each well of the six-well slides. Lysosyme was added with certain types of probes, such as, Lab158, to ensure sufficient permeability of the cell envelope, and allowing the probes to enter cells efficiently. Slides were then dehydrated in 50, 80 and $96 \%$, respectively, and hybridisation mix was added to the wells. Hybridisation was set to the appropriate temperature, according to the type of probe used. Once the hybridisation mix was added to all the wells, slides were added in an oven for $4 \mathrm{~h}$. Slides were removed after the incubation period, and placed in a washing solution to remove any residuals. Then $20 \mu \mathrm{l}$ of DAPI (4',6'-diamino-2-phenylindole) were added to the washing solutions, which allowed the cells in the samples to be easily found under the microscope. Antifade ( $5 \mu$ l; Sigma Aldrich) was added to all the wells when slides were dried and a coverslip was placed on them to be ready for microscopic enumeration. Slides were stored in an opaque closed box in the fridge. The number of bacterial cells was counted using fluorescence microscopy (Nikon Eclipse E400; Nikon), which had an appropriate filter for the DAPI stain (excited at $359 \mathrm{~nm}$ and emits at $461 \mathrm{~nm}$ ) and Cy3 dye (excited at $550 \mathrm{~nm}$ and emits at $565 \mathrm{~nm}$ ). Fifteen to twenty fields were counted for each well in each six-well slide (Tekdon Inc.).

\section{Identification and quantification of bacterial metabolites}

Phenolic compounds. DDE were centrifuged at $13000 \mathrm{~g}$ for $5 \mathrm{~min}$ to remove all particulate matter and filtered through $0.45 \mu \mathrm{m}$ acrodisc filters before injection $(50 \mu \mathrm{l})$ onto the HPLC system. HPLC analysis was performed using an Agilent 1100 Series linked to diode array detector. Separation of compounds was achieved using a C18 Nova Pak ${ }^{\circledR}$ column $(250 \mathrm{~mm} \times 4.6 \mathrm{~mm}$ internal diameter, $5 \mu \mathrm{m}$ particle size), fitted with a guard column (C18 NovaPak ${ }^{\circledR}$; Waters Ltd). The mobile phase consisted of A: 5 M-hydrochloric acid $(0.1 \%)$ in $5 \%$ aqueous methanol; and B: 5 m-hydrochloric acid $(0.1 \%)$ in aqueous acetonitrile $(1: 1)$ and was pumped through the column at $0.7 \mathrm{ml} / \mathrm{min}$. Samples $(50 \mu \mathrm{l})$ were injected and separated using the following gradient system ( $\mathrm{min} / \% \mathrm{~B}): 0 / 5,5 / 5,40 / 50,55 /$ $100,59 \cdot 9 / 100$ and $60 / 5$ for the detection of all compounds. The eluent was monitored by photodiode array detection at 254, 280, 320, 370 and $520 \mathrm{~nm}$ and spectra of products obtained over the 220-600 nm range. Phenolic compounds were characterised by their retention time and by 
comparison with known phenolic standards $(0-100 \mu \mathrm{M} ; \mathrm{R}>$ 0.995). All data were analysed using ChemStation ${ }^{\circledR}$ software. For identification of phenolic compounds, we used different standards, such as phenolic compound standards including gallic, protocatechuic, $p$-hydroxybenzoic, vanillic, isovanillic, caffeic, syringic, $p$-coumaric, ferulic, isoferulic and sinapic acids, (+)-catechin, (-)-epicatechin, rutin, myricetin, quercetin, luteolin, naringenin, kaempferol, isorhamnetin, apigenin and petunidin (Sigma Aldrich).

Liquid chromatography-electrospray ionisation-MS/MS analysis. Methanol extracts were also analysed by liquid chromatography-MS/MS utilising electrospray ionisation. This consisted of an Agilent 1200 HPLC system equipped with a binary pump, degasser, autosampler, thermostat, column heater; photodiode array detector and an Agilent 1100 Series LC/MSD mass trap spectrometer. Separation of samples was achieved using a Zorbax SB C18 column $(2.1 \times 100 \mathrm{~mm} ; 1.8 \mu \mathrm{m} ;$ Agilent $)$ and HPLC conditions were as follows: injection volume, $5 \mu \mathrm{l}$; column temperature, $25^{\circ} \mathrm{C}$; binary mobile system, (A) $0.1 \%$ aqueous formic acid and (B) $0.1 \%$ of formic acid in acetonitrile; flow rate, $0.2 \mathrm{ml} /$ min. A series of linear gradients were used for separation $(\min / \% B): 0 / 10,3 / 10,15 / 40,40 / 70,50 / 70$ and $65 / 10$. MS was performed in the negative ion mode (scan range, $m /$. 100-800 Da; source temperature, $350^{\circ} \mathrm{C}$ ). All solvents used were of liquid chromatography-MS grade.

SCFA. DDE were centrifuged at $13000 \mathrm{~g}$ for $5 \mathrm{~min}$ to remove all particulate matter and supernatant fractions were filtered through $0.2 \mu \mathrm{m}$ acrodisc filters before injection $(20 \mu \mathrm{l})$ onto the HPLC system (MERCK) equipped with refractive index (RI) detection. Separation of compounds was achieved using an ion-exclusion REZEX-ROA Organic acid column (Phenomenex) maintained at $85^{\circ} \mathrm{C}$. Sulfuric acid in HPLCgrade water $(0.0025 \mathrm{mmol} / \mathrm{l})$ was used as an eluent and the flow rate was maintained at $0.5 \mathrm{ml} / \mathrm{min}$. Quantification of the samples was obtained through calibration curves of lactic, acetic, propionic, butyric and valeric acids in concentrations between 12.5 and $100 \mathrm{~mm}$.

\section{Caco-2 cancer growth}

DDE and DPE were tested for the percentage growth inhibition of Caco- 2 cells before and after $\mathrm{pH}$-controlled batch culture fermentation at 0 and $10 \mathrm{~h}$, relative to untreated cells. Samples were centrifuged at $13000 \mathrm{~g}$ for $10 \mathrm{~min}$ to remove all particulate matter and supernatant fractions were filtered through $0.22 \mu \mathrm{m}$ acrodisc filters. Caco-2 cells European Collection of Cell Cultures (ECACC) (http://www.ecacc. org/)) were cultured in Dulbecco's modified Eagle's medium, supplemented with $20 \%$ heat-inactivated bovine serum, 2 mM-L-glutamine, $1 \%$ non-essential amino acids, $100 \mathrm{U} / \mathrm{ml}$ penicillin and $100 \mu \mathrm{g} / \mathrm{ml}$ streptomycin (PAA Cell Culture Company). Anti-proliferative ability was assessed using the SRB assay. Cells were seeded in twenty-four-well plates at low confluence $\left(5 \times 10^{4}\right.$ per well $)$ and exposed to all extracts
$(0 \cdot 2 \mathrm{mg} / \mathrm{ml})$. Cells were harvested following 24,48 and $72 \mathrm{~h}$ in culture and fixed by the addition of $125 \mu \mathrm{l}$ ice-cold TCA $\left(10 \%\right.$ final concentration; $\left.4^{\circ} \mathrm{C} ; 1 \mathrm{~h}\right)$. After fixing, the medium was removed, cells were washed and total biomass determined using SRB $(500 \mu \mathrm{l}$ of $0.4 \%$ SRB; $0.5 \mathrm{~h})$ (Sigma Aldrich). Unincorporated dye was removed by washing with $1 \%$ acetic acid, whilst cell incorporated dye was solubilised using Trisbase (10 mM). Dye incorporation, reflecting cell biomass, was measured at $492 \mathrm{~nm}$, using a GENios microplate reader (TECAN).

\section{Statistical analysis}

DDE and DPE were tested in two different $\mathrm{pH}$-controlled batch-culture experiments, using three different donors in three separate experiments. Changes in both bacterial counts $\left(\log _{10}\right)$ and SCFA $(\mathrm{mm})$ were expressed relative to the control and standard deviation. Changes in the percentage growth inhibition in Caco- 2 cells were measured relative to untreated cells. One-way ANOVA was applied to show significant differences among different time points of fermentation $(0,5$, 10, 24 and 48 h). Significant differences between times points were detected using least significant difference (LSD) tests. SPSS software, version 18.0, was used (IBM).

Dietary fibre were analysed by Campden BRI Laboratories (AOAC method 991.43); Ajwa total fibre content is 6.85$7 \cdot 9 \mathrm{~g} / 100 \mathrm{~g}(6 \cdot 15-7 \cdot 2 \mathrm{~g}$ insoluble fibre).

\section{Results}

\section{Effects of digested date extract and date polyphenol extract in} specific bacterial groups

Selected bacterial groups were assessed by FISH following faecal batch-culture fermentation experiments using DDE and DPE. Results indicated that both were capable of inducing significant modulation in the growth of specific bacterial groups at different time points (Tables 1 and 2). DDE significantly increased bifidobacteria $(P<0.05)$ at 5 and $10 \mathrm{~h}$, and also a change in bacteroides at $24 \mathrm{~h}(P<0.05)$, along with changes in total bacterial counts $(P<0 \cdot 05)$ (Table 1). In contrast, DPE significantly increased bifidobacteria at $5 \mathrm{~h}(P<0.05)$, whereas a decrease in bacteroides at $48 \mathrm{~h}(P<0.05)$ was seen. Overall, DPE exhibited a weaker impact on bifidobacteria counts. In comparison with the prebiotic FOS, even though both DDE and DPE exhibited a bifidogenic effect, it was significantly smaller than FOS at different time points. DDE was much closer to FOS in its impact on bacterial composition change than DPE, where polyphenols have been shown to reduce bacteroides counts.

\section{Changes in bacterial metabolites}

To investigate how different bioactive compounds in date fruits (polyphenols and fibres) were metabolised by the faecal microbiota, we utilised HPLC analysis to analyse SCFA after DDE fermentation and polyphenols after DPE fermentation. 
Table 1. Faecal bacterial numbers in three $\mathrm{pH}$-controlled batch cultures over $48 \mathrm{~h}$ periods $\dagger$ (Mean values and standard deviations)

\begin{tabular}{|c|c|c|c|c|c|c|c|c|c|c|c|c|c|c|}
\hline \multirow[t]{2}{*}{ Probe... } & \multicolumn{2}{|c|}{ Bif164 } & \multicolumn{2}{|c|}{ Lab158 } & \multicolumn{2}{|c|}{ Ato291 } & \multicolumn{2}{|c|}{ Вас303 } & \multicolumn{2}{|c|}{ Erec482 } & \multicolumn{2}{|c|}{ Chis150 } & \multicolumn{2}{|c|}{ Eub I-II-III } \\
\hline & Mean & SD & Mean & SD & Mean & SD & Mean & SD & Mean & $\mathrm{SD}$ & Mean & $\mathrm{SD}$ & Mean & SD \\
\hline FOS (0 h) & 7.88 & 0.30 & 6.01 & 0.79 & 7.50 & 0.11 & $8 \cdot 21$ & 0.07 & 8.44 & 0.01 & 5.56 & 0.01 & $9 \cdot 18$ & 0.24 \\
\hline FOS (5 h) & $8.09^{\star}$ & 0.33 & $6 \cdot 69^{\star}$ & 0.45 & 7.69 & 1.04 & $8 \cdot 12$ & 0.19 & 8.67 & 0.37 & $6 \cdot 15$ & 0.08 & $9 \cdot 00^{*}$ & 0.16 \\
\hline FOS (10 h) & $8.53^{\star *}$ & 0.21 & $6 \cdot 13$ & 0.98 & $7 \cdot 70$ & 1.20 & 8.06 & 0.46 & $8 \cdot 81$ & 0.41 & $5 \cdot 76$ & 0.00 & $9 \cdot 38^{*}$ & 0.11 \\
\hline FOS (24 h) & $8 \cdot 34^{\star}$ & 0.16 & 5.98 & 0.74 & $7 \cdot 72$ & 0.80 & $8 \cdot 23$ & 0.17 & 8.66 & 0.39 & $5 \cdot 55$ & 0.02 & 9.27 & 0.05 \\
\hline FOS (48 h) & $8 \cdot 47^{*}$ & 0.05 & $6 \cdot 07$ & 0.57 & $7 \cdot 74$ & 0.98 & 8.08 & 0.21 & $8 \cdot 82$ & 0.36 & 5.55 & 0.02 & $9 \cdot 44^{\star *}$ & 0.14 \\
\hline DDE (0 h) & $7 \cdot 83$ & 0.36 & $6 \cdot 11$ & 0.10 & $7 \cdot 28$ & 0.49 & 8.09 & 0.43 & $8 \cdot 27$ & 0.23 & 5.56 & 0.01 & 9.06 & 0.20 \\
\hline DDE (5 h) & $8 \cdot 24^{\star}$ & 0.20 & $6 \cdot 15$ & 0.75 & 7.59 & 0.97 & $7 \cdot 73$ & 0.23 & $7 \cdot 91$ & 0.66 & 5.56 & 0.01 & 8.92 & 0.34 \\
\hline DDE (10 h) & $8 \cdot 21^{*}$ & 0.20 & $6 \cdot 25$ & 0.86 & $7 \cdot 71$ & $1 \cdot 16$ & 7.90 & 0.44 & 8.56 & 0.46 & 5.56 & 0.01 & $9 \cdot 15$ & 0.26 \\
\hline DDE (24 h) & $8 \cdot 22$ & 0.32 & $5 \cdot 75$ & 0.59 & $7 \cdot 86$ & 0.80 & $8 \cdot 20^{*}$ & 0.07 & 8.66 & 0.28 & 5.55 & 0.02 & $9 \cdot 40^{*}$ & 0.03 \\
\hline DDE (48 h) & 8.28 & 0.53 & $6 \cdot 19$ & 0.74 & $7 \cdot 81$ & 0.74 & 7.96 & 0.20 & 8.54 & 0.53 & 5.55 & 0.02 & $9 \cdot 41^{*}$ & 0.12 \\
\hline
\end{tabular}

FOS, fructo-oligosaccharides; DDE, digested date extract.

Mean value was significantly different from that at $0 \mathrm{~h}$ fermentation: ${ }^{*} P<0.05,{ }^{\star *} P<0.01$ (one-way ANOVA and least significant difference (LSD) test).

$\dagger$ Bacterial counts in fermented faecal samples were determined by fluorescence in situ hybridisation and are expressed as log ${ }_{10}$ cells/g faeces.

Table 2. Faecal bacterial numbers in three $\mathrm{pH}$-controlled batch cultures over $48 \mathrm{~h}$ periods +

(Mean values and standard deviations)

\begin{tabular}{|c|c|c|c|c|c|c|c|c|c|c|c|c|c|c|}
\hline \multirow[t]{2}{*}{ Probe... } & \multicolumn{2}{|c|}{ Bif164 } & \multicolumn{2}{|c|}{ Lab158 } & \multicolumn{2}{|c|}{ Ato291 } & \multicolumn{2}{|c|}{ Bac303 } & \multicolumn{2}{|c|}{ Erec482 } & \multicolumn{2}{|c|}{ Chis150 } & \multicolumn{2}{|c|}{ Eub I-II-III } \\
\hline & Mean & SD & Mean & SD & Mean & SD & Mean & SD & Mean & SD & Mean & SD & Mean & SD \\
\hline FOS (0 h) & $8 \cdot 34$ & 0.23 & $6 \cdot 06$ & 0.49 & $7 \cdot 75$ & 0.09 & $8 \cdot 33$ & 0.17 & $8 \cdot 18$ & 0.23 & 5.59 & 0.07 & 8.96 & 0.05 \\
\hline FOS (5 h) & 8.53 & 0.31 & 6.55 & 0.60 & 7.90 & 0.08 & 8.08 & 0.38 & $7 \cdot 82$ & 0.43 & 5.79 & 0.53 & 9.05 & 0.24 \\
\hline FOS (10 h) & 8.55 & 0.31 & $6 \cdot 86^{\star}$ & 0.43 & $8 \cdot 23^{*}$ & 0.08 & $8 \cdot 18$ & 0.36 & $8 \cdot 11$ & 0.24 & $6 \cdot 21$ & 0.72 & $9 \cdot 20^{*}$ & 0.03 \\
\hline FOS (24 h) & 8.55 & 0.26 & $7 \cdot 04^{*}$ & 0.42 & $7 \cdot 72$ & 0.30 & 7.99 & 0.36 & $8 \cdot 25$ & 0.08 & 5.47 & 0.15 & $9 \cdot 43^{\star \star}$ & 0.03 \\
\hline FOS (48 h) & $8 \cdot 69^{*}$ & 0.16 & $7.02^{*}$ & 0.49 & $8 \cdot 16^{*}$ & 0.04 & 7.90 & 0.34 & 7.99 & 0.29 & 5.53 & 0.17 & $9 \cdot 33$ & 0.19 \\
\hline DPE (0 h) & $8 \cdot 13$ & 0.10 & 5.98 & 0.61 & 7.95 & 0.27 & 8.27 & 0.22 & $8 \cdot 29$ & 0.18 & 5.85 & 0.63 & $9 \cdot 11$ & 0.11 \\
\hline DPE (5 h) & $8 \cdot 24^{*}$ & 0.15 & $6 \cdot 22$ & 0.47 & $7 \cdot 70$ & 0.44 & 7.94 & 0.14 & 8.03 & 0.18 & 5.77 & 0.38 & $9 \cdot 15$ & 0.19 \\
\hline DPE (10 h) & $8 \cdot 20$ & 0.13 & $6 \cdot 35$ & 0.42 & $7 \cdot 77$ & 0.18 & 8.03 & 0.12 & 7.97 & 0.21 & $5 \cdot 84$ & 0.39 & $9 \cdot 24$ & 0.05 \\
\hline DPE (24 h) & $8 \cdot 32$ & 0.15 & $6 \cdot 34$ & 0.63 & $7 \cdot 71$ & 0.37 & 7.94 & 0.26 & 8.03 & 0.26 & $5 \cdot 60$ & 0.32 & $9 \cdot 26$ & 0.12 \\
\hline DPE (48 h) & $8 \cdot 18$ & 0.24 & $6 \cdot 42$ & 0.62 & 7.54 & 0.21 & $7 \cdot 83^{*}$ & 0.31 & $7 \cdot 86$ & 0.08 & 5.53 & 0.17 & 9.24 & 0.18 \\
\hline
\end{tabular}

FOS, fructo-oligosaccharides; DPE, date polyphenol extract.

Mean value was significantly different from that at $0 \mathrm{~h}$ fermentation: ${ }^{\star} P<0.05,{ }^{\star \star} P<0.01$ (one-way ANOVA and least significant difference (LSD) test).

$\dagger$ Bacterial counts in fermented faecal samples were determined by fluorescence in situ hybridisation and are expressed as log ${ }_{10}$ cells $/ g$ faeces.

With regards to DDE fermentation, there were increases in acetate, propionate, butyrate and lactate among time points in comparison with $0 \mathrm{~h}$. However, a significant increase $(P<0.05)$ was only observed with acetate concentrations at $48 \mathrm{~h}$ fermentation (Table 3). With regards to DPE fermentation, there were significant reductions in luteolin at $10 \mathrm{~h}$ $(P<0 \cdot 05), 24 \mathrm{~h}$ and $48 \mathrm{~h}$ and quercetin $(P<0 \cdot 01)$ concentrations in comparison with $0 \mathrm{~h}$ whereas apigenin and petunidin were significantly reduced $(P<0.05)$ at $5 \mathrm{~h}$ fermentation (Table 4). The current batch culture confirms the presence of petunidin at a higher level, in comparison with other aglycones as seen in previous work ${ }^{(33)}$.

\section{Caco-2 cell proliferation}

We also assessed the ability of DDE, DPE and metabolites generated by fermentation to inhibit colon cancer cell proliferation (Fig. 1). Here, both extracts induced significant antiproliferative action before and following bacterial fermentation. Specifically, DDE had a significantly $(P<0 \cdot 05)$ greater ability

Table 3. SCFA concentrations in three $\mathrm{pH}$-controlled batch cultures over $48 \mathrm{~h}$ periods $\dagger$ (Mean values and standard deviations)

\begin{tabular}{|c|c|c|c|c|c|c|c|c|c|c|}
\hline \multirow[t]{2}{*}{ Time... } & \multicolumn{2}{|c|}{$\mathrm{Oh}$} & \multicolumn{2}{|c|}{$5 \mathrm{~h}$} & \multicolumn{2}{|c|}{$10 \mathrm{~h}$} & \multicolumn{2}{|c|}{$24 \mathrm{~h}$} & \multicolumn{2}{|c|}{$48 \mathrm{~h}$} \\
\hline & Mean & $\mathrm{SD}$ & Mean & $\mathrm{SD}$ & Mean & SD & Mean & SD & Mean & $\mathrm{SD}$ \\
\hline Lactate (mм) & $2 \cdot 10$ & 3.64 & $6 \cdot 17$ & $10 \cdot 69$ & 7.94 & 13.75 & 11.47 & 12.06 & $6 \cdot 24$ & 5.47 \\
\hline Formate (mм) & $9 \cdot 44$ & $10 \cdot 44$ & 14.46 & 11.93 & $5 \cdot 73$ & 5.54 & $5 \cdot 18$ & 5.00 & $5 \cdot 16$ & 5.00 \\
\hline Acetate (mм) & $13 \cdot 26$ & 12.47 & 25.01 & $17 \cdot 73$ & 22.96 & 17.89 & $45 \cdot 77$ & 13.60 & $45 \cdot 35^{\star}$ & 1.40 \\
\hline Propionate (mm) & $6 \cdot 38$ & 1.69 & 9.07 & $2 \cdot 34$ & $12 \cdot 82$ & $10 \cdot 79$ & 11.64 & $4 \cdot 86$ & 9.97 & 3.76 \\
\hline Butyrate (mм) & 3.99 & 3.5 & 4.98 & $2 \cdot 30$ & $5 \cdot 15$ & 5.81 & $7 \cdot 51$ & $5 \cdot 31$ & $10 \cdot 41$ & 2.99 \\
\hline Valerate (mм) & 1.44 & 2.49 & 1.51 & 2.59 & 1.66 & $2 \cdot 88$ & 1.03 & 1.78 & 0.49 & 0.86 \\
\hline
\end{tabular}

* Mean value was significantly different from that at $0 \mathrm{~h}$ fermentation $(P<0.05$; ANOVA and least significant difference (LSD) test)

$\uparrow$ Metabolite counts in fermented faecal samples were determined by HPLC. 
Table 4. Aglycone concentrations in three pH-controlled batch cultures over $48 \mathrm{~h}$ periods $\ddagger$ (Mean values and standard deviations)

\begin{tabular}{|c|c|c|c|c|c|c|c|c|c|c|}
\hline \multirow[t]{2}{*}{ Time... } & \multicolumn{2}{|c|}{$\mathrm{Oh}$} & \multicolumn{2}{|c|}{$5 \mathrm{~h}$} & \multicolumn{2}{|c|}{$10 \mathrm{~h}$} & \multicolumn{2}{|c|}{$24 \mathrm{~h}$} & \multicolumn{2}{|c|}{$48 \mathrm{~h}$} \\
\hline & Mean & SD & Mean & SD & Mean & SD & Mean & SD & Mean & SD \\
\hline Myricetin (mм) & 0.21 & 0.07 & 0.19 & 0.06 & 0.25 & 0.05 & 0.21 & 0.06 & 0.21 & 0.03 \\
\hline Luteolin (mм) & 0.32 & 0.04 & $0.16 \dagger$ & 0.02 & $0.15^{*}$ & 0.02 & $0.00^{* *}$ & 0.00 & $0.00^{* *}$ & 0.00 \\
\hline Quercetin (тм) & 0.30 & 0.03 & $0.18 \dagger$ & 0.02 & 0.18 & 0.07 & $0.00^{* *}$ & 0.00 & $0.00^{\star *}$ & 0.00 \\
\hline Apigenin (mм) & 0.00 & 0.00 & $0.31^{*}$ & 0.12 & 0.14 & 0.29 & 0.00 & 0.00 & 0.00 & 0.00 \\
\hline Petunidin (mм) & 0.95 & 0.29 & $0.37^{\star}$ & 0.11 & 0.43 & 0.19 & 0.33 & 0.185 & 0.30 & 0.19 \\
\hline
\end{tabular}

* Mean value was significantly different from that at $0 \mathrm{~h}$ fermentation: ${ }^{*} P<0.05,{ }^{* \star} P<0.01$ (one-way ANOVA and least significant difference (LSD) test). † Mean value was borderline significantly different from that at $0 \mathrm{~h}$ fermentation $(P>0.05$; one-way ANOVA and least significant difference (LSD) test). $\ddagger$ Polyphenol compound counts in fermented faecal samples were determined by HPLC.

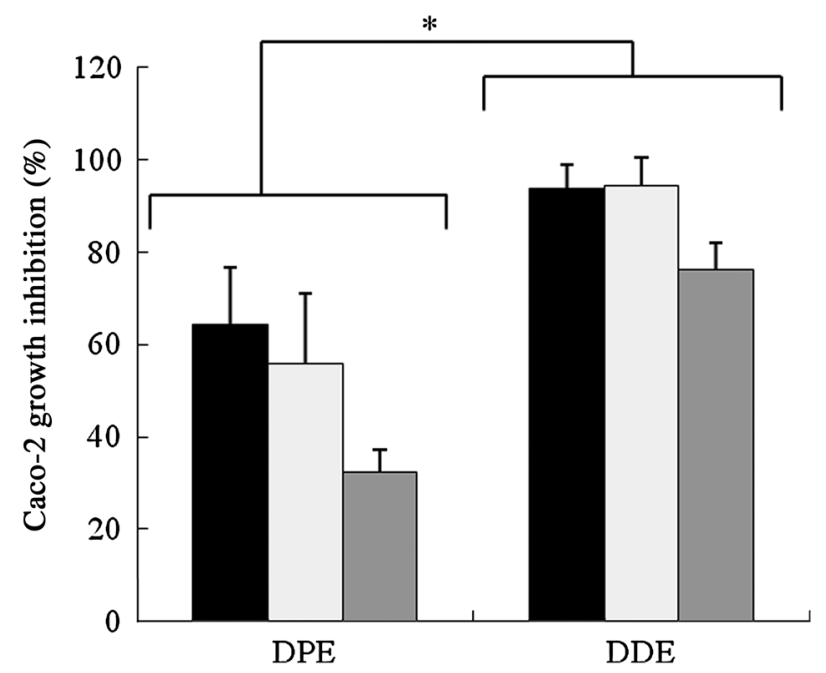

Fig. 1. Caco-2 growth inhibition percentages measured in $\mathrm{pH}$-controlled batch cultures over $48 \mathrm{~h}$ periods: $\square$, before fermentation; $\square, 10 \mathrm{~h}$ fermentation; $48 \mathrm{~h}$ fermentation. Percentages were measured by spectrophotometer at $570 \mathrm{~nm}$. Values are means, with standard deviations represented by vertical bars. * Mean values for date polyphenol extract (DPE) were significantly different from those for digested date extract (DDE) $(P<0.05$; one-way ANOVA and least significant difference (LSD) test).

to reduce the growth of Caco-2 cells than DPE, inducing about $90 \%$ of inhibition at $48 \mathrm{~h}$ of exposure. Fermentation was observed to decrease overall cancer cell growth inhibition, only achieving a $30 \%$ inhibition with DPE and $70 \%$ inhibition with DDE after $48 \mathrm{~h}$ fermentation.

\section{Discussion}

The present study has provided evidence that both DDE and DPE derived from Ajwa dates are able to significantly increase the growth of beneficial bacteria, such as bifidobacteria in human faecal batch cultures. Such changes in the growth of these bacteria may play a role in enhancing colon health, by inhibiting the growth of pathogens and increasing the production of acetate and lactate ${ }^{(47)}$. Previous studies have indicated that malvidin-3-glycoside $(200 \mathrm{mg} / \mathrm{l})$ may induce significant increases in bifidobacteria, lactobacilli and total bacteria ${ }^{(15)}$, fitting well with our observation in that the Ajwa dates used are, unlike other dates, rich in anthocyanins ${ }^{(33)}$. With regards to other bacterial groups tested, lactobacilli and $C$. histolyticum did not change with either of the treatments. Such data indicate a selective effect on the growth of specific bacteria, something that is commonly seen with prebiotics such as FOS $^{(15)}$. The number of bacteroides, on the other hand, was significantly increased at $24 \mathrm{~h}$ of exposure to DDE, but was decreased when exposed to DPE. Bacteroides are considered a dominant bacterial group in the large intestine and are known to produce propionate when they ferment dietary fibres from oats and barley ${ }^{(8)}$. In previous studies, limited changes have been found with bacteroides after polyphenol- and/or fibre-rich foods. In the present study, the decrease in bacteroides seen with DPE fermentation may be due to the use of pure polyphenol extracts, where polyphenols exhibit the ability to bind to bacterial cells membranes, thus inhibiting their growth. Differences between polyphenols' antimicrobial activities depend also on the bacterial lipid bilayer, which may have a greater affinity to inhibit Gram-negative bacteria, such as bacteroides ${ }^{(48)}$. On the other hand, with DDE, the presence of fibres, and cleaved sugars from polyphenol glycosides should interfere with the selectivity of bacterial growth, where bacteroides and total bacteria were seen to be increased.

The whole Ajwa dates (DDE) were also observed to induce an increased trend in the Atopobium-Coriobacterium group at all time points, which is something previously observed with oat and barley fermentation, containing similar amounts of insoluble fibres ${ }^{(8)}$. Atopobium spp. have recently been reported as being capable of modulating caspase- 9 and caspase- 3 in a manner known to induce apoptosis and inhibiting Caco-2 cancer growth in vitro ${ }^{(49)}$. In addition, an increased trend in the growth of $C$. coccoides-E. rectale with DDE was also observed. This bacterial group is believed to produce butyrate, which is considered protective with respect to effects on colon cancer $^{(50)}$ and ulcerative colitis ${ }^{(51)}$. Furthermore, some species of the Coccoides-Eubacterium group are thought to reduce cancer risks due to butyrate production ${ }^{(52)}$, again through an inhibition of apoptosis ${ }^{(53)}$. Previously, most interest has focused on the potential of established prebiotics to increase the growth of bifidobacteria and lactobacilli, with little interest in the growth of other types of bacteria such as Atopobium spp., E. rectale spp. and Roseburia that may be capable of exerting anti-cancer abilities ${ }^{(49)}$. Costabile et al. revealed an increase in Atopobium spp. following the consumption of inulin extracted from artichokes in human subjects ${ }^{(19)}$, and butyrateproducing bacteria via polydextrose consumption ${ }^{(54)}$. Therefore, our findings must be tested in a larger number of volunteers to ascertain such changes. 
The present study shows a bifidogenic effect with both whole date extracts and polyphenol extracts ${ }^{(6,11)}$, where a possible potential is worth testing in human subjects. The effects of polyphenols on the growth of the gut microbiota appear to depend on their structure. For example, no changes in the growth of lactobacilli or bacteroides were observed after exposure to catechins ${ }^{(12)}$ and proanthocyanidins ${ }^{(16)}$, whereas with wine phenolic extracts ${ }^{(13)}$, and flavanol-3-ols present in grape seed, significant increases were observed ${ }^{(17)}$. Rather, our data show that there was a selective shift in the bacterial population of the large intestine, with whole date fruit (DDE), but still considered a weak bifidogenic impact when compared with cereals ${ }^{(6,8)}$. A fraction of such impact should be due to the presence of polyphenols, where bifidobacteria have been seen to be significantly increased via inoculation. Questions remain as to the extent to which polyphenols have the ability to modulate the gut microbiota towards a healthier state, with PCR, DNA sequencing, metabonomics and metabolomics required to fully understand the mechanisms involved in polyphenol fermentation ${ }^{(55)}$ and whether there may be synergetic actions of both polyphenols and dietary fibres on bacterial growth in the large gut. In order to exert such effects in the large intestine, date polyphenols and fibres must escape metabolism in the upper gastrointestinal tract, thus reaching the colon intact where they may exhibit functional properties within. Previous studies have suggested that up to $80 \%$ of polyphenols similar to those identified in dates ${ }^{(33)}$ may reach the $\operatorname{colon}^{(37)}$, where they are then hydrolysed by bacteria and further metabolised to smaller molecular-weight phenolic endproducts ${ }^{(36,56)}$. According to Tzounis et al. ${ }^{(12)}$. HPLC chromatograms showed that $50 \%$ of flavanol monomers are metabolised by the gut bacteria, with $(+)$-catechin being converted to $(+)$-epicatchein. Date fruits are known to contain high amounts of phenolic acids, procyanidins and flavonoid glycosides ${ }^{(31,33)}$. In the present study, myrecitin, luteolin, quercetin and apigenin and the anthocyanidin petunidin were all detected, presumably following cleavage of their corresponding glycoside to the aglycone. Previously, it has been suggested that flavonoid glycosides and anthocyanins undergo rapid hydrolysis by various gut bacteria, such as E. ramulus, to produce aglycones and other endproducts via the actions of microbial glycosidase leading to flavonoid ring fission ${ }^{(48)}$, and/or the action of Bifidobacterium lactis ${ }^{(57)}$. The more rapid metabolism of polyphenols in the DPE, relative to the whole date, is expected to be due to matrix effects, with polyphenols needing initial release in the whole fruit before any bacterial metabolism can take place ${ }^{(15)}$. In the present data, we observed the rapid formation of aglycones, probably as a result of specific bacterial enzymes that cleave the 3 -glycosidic linkage, and the later production of phenolic acids, such as syringic acids, p-coumaric acids and gallic acids, as seen with malvidin glycosides in batch cultures ${ }^{(58)}$. In another study, peonidin-3-glycoside and cyanidin-3glycoside degradation by the gut mircobiota resulted in the production of vanillic acids and protocatechuic acids ${ }^{(59)}$. Such compounds have been seen in previous work to induce apoptosis in colon cancer cell lines and interfere with the cellular signalling ${ }^{(60)}$.
SCFA are also produced as a result of saccharolytic metabolism of gut microbiota in the large intestine ${ }^{(4)}$. HPLC analysis was used to identify and quantify the main SCFA produced in batch cultures, indicating a significant increase in acetate concentrations, seen at $48 \mathrm{~h}$, which was mostly associated with the increase in bifidobacteria numbers. Previous investigations have demonstrated a direct relationship between changes in bifidobacteria and acetate when pomegranate by-products were inoculated in batch cultures, whereas when punicalagins (pomegranate ellagitannins) were added no effects were detected in bacteria or in SCFA production, which indicates that modifications in the gut ecology were mostly due to other bioactive compounds, such as insoluble fibres ${ }^{(14)}$. The extent of degradation and metabolism of dietary components by bacterial enzymes depends on the different composition of bacteria within different volunteers, something that will contribute to the bioavailability and production of metabolic endproducts. In the present study, the increase in butyrate was not significant, which is mainly associated with butyrate-producing bacteria, C. coccoides-E. rectale that was not significantly affected following their exposure to DDE. The explanation behind the relatively slow production of SCFA following exposure to whole date fruit could again be the complex matrix ${ }^{(48)}$. In addition, donor diets may play crucial roles in colon metabolism, where the presence of other foods ingredients, such as proteins, could be involved in bacterial fermentation. As a result of bacterial hydrolysis, other by-products, such as bile acids and ammonia, could also interfere with the gut ecology ${ }^{(61)}$. SCFA such as butyrate are thought to be involved in colon cancer inhibition ${ }^{(62)}$. Changes in the colonic microflora, together with the production of metabolic products (SCFA and phenolic acids) may work together to exhibit an anti-cancer effect in the colon, thus enhancing gut health.

There is still debate as to whether foods rich in polyphenols and dietary fibres may prevent colon cancer in humans, as clinical data remain inconclusive ${ }^{(63,64)}$. However, the fact that we observed the potential of date polyphenols to induce apoptosis even after metabolism by the microbiota suggests that date intake may be capable of exerting anti-carcinogenic activity. Previously, polyphenols extracted from olive oil have also been shown to exert strong anti-proliferative effects in Caco-2 cell lines, along with changes in cellular signalling ${ }^{(65,66)}$. This anti-cancer effect was dose dependent and still apparent after bacterial metabolism of the original polyphenols in the extract. In the pure extracts, the presence of phenolic acids, flavonoid glycosides and anthocyanins contributed to a strong inhibition in Caco-2 cell lines, whereas with fermentation, inhibition was weaker due to the loss of phenolic acids and other possible unidentified compounds, which do not reach the colon. What was detected with the fermented extracts is more similar to the human dietary intake, which needs to be proved in human trials.

The present paper represents an early investigation into the influence of date fruit and date polyphenols on the growth of large-intestinal bacteria and related metabolites. The whole date fruit extract was capable of larger effects on bacterial growth than that seen with the date polyphenols alone, due to the presence of insoluble fibres, where polyphenols 
themselves showed a weaker ability to modify bacterial counts. Furthermore, these data were paralleled by changes in bacterial metabolic products; both SCFA and phenolic acids following incubation with the faecal microbiota were shown to inhibit colon cancer cell growth. The present results suggest that the synergistic action of both date polyphenols and insoluble fibres could enhance colonic health.

\section{Acknowledgements}

Sincere appreciation to Mr Sulaiman Al-Gudaibi who supplied this research with all date palm fruits, from Al Gudaibi farms, Al Qassim, Saudi Arabia. We also thank Virginia Lewis, BSc student at the Food and Nutritional Sciences department for helping out with the microbiology work.

We thank the Ministry of Education in Saudi Arabia for the sponsorship of N. E.

Contributions of the authors were as follows: N. E. designed and carried all experiments, results, data analysis, statistics and writing of the paper under the supervision of J. P. E. S.; S. E. (MSc student) helped with cell work; G. W. provided laboratory guidance in microbiology (batch cultures and FISH analysis); G. C. provided laboratory guidance in cell work (cell culture, SRB assay); A. C. provided laboratory guidance in metabolites (SCFA); G. G. provided N. E. with the opportunity to work in the FMSU (Food Microbial Sciences Unit at University of Reading) laboratory and use of batch cultures; I. R. was the project second supervisor; J. P. E. S. was the project first supervisor, and corresponding author. Each author contributed to the paper drafting.

There are no conflicts of interest to declare.

\section{References}

1. Roberfroid M, Gibson GR, Hoyles L, et al. (2010) Prebiotic effects: metabolic and health benefits. Br J Nutr 104, Suppl. S2, S1-S63.

2. Wallace TC, Guarner F, Madsen K, et al. (2011) Human gut microbiota and its relationship to health and disease. Nutr Rev 69, 392-403.

3. Gibson GR, Scott KP, Rastall RA, et al. (2010) Dietary prebiotics: current status and new definition. Food Sci Tech Bull Funct Foods 7, $1-19$.

4. Rastall RA, Gibson GR, Gill HS, et al. (2005) Modulation of the microbial ecology of the human colon by probiotics, prebiotics and synbiotics to enhance human health: an overview of enabling science and potential applications. FEMS Microbiol Ecol 52, 145-152.

5. Tuohy KM, Kolida S, Lustenberger AM, et al. (2001) The prebiotic effects of biscuits containing partially hydrolysed guar gum and fructo-oligosaccharides - a human volunteer study. Br J Nutr $\mathbf{8 6}$, 341-348.

6. Connolly ML, Lovegrove JA \& Tuohy KM (2010) In vitro evaluation of the microbiota modulation abilities of different sized whole oat grain flakes. Anaerobe 16, 483-488.

7. Sarbini SR, Kolida S, Naeye T, et al. (2011) In vitro fermentation of linear and $\alpha-1,2$-branched dextrans by the human fecal microbiota. Appl Environ Microbiol 77, 5307-5315.

8. Hughes SA, Shewry PR, Gibson GR, et al. (2008) In vitro fermentation of oat and barley derived $\beta$-glucans by human faecal microbiota. FEMS Microbiol Ecol 64, 482-493.

9. Jaskari J, Kontula P, Siitonen A, et al. (1998) Oat $\beta$-glucan and xylan hydrolysates as selective substrates for Bifidobacterium and Lactobacillus strains. Appl Microbiol Biotech 49, 175-181.
10. Kedia G, Vázquez J, Charalampopoulos D, et al. (2009) In vitro fermentation of oat bran obtained by debranning with a mixed culture of human fecal bacteria. Curr Microbiol 58, 338-342.

11. Beards E, Tuohy K \& Gibson G (2010) Bacterial, SCFA and gas profiles of a range of food ingredients following in vitro fermentation by human colonic microbiota. Anaerobe 16, 420-425.

12. Tzounis X, Vulevic J, Kuhnle GGC, et al. (2008) Flavanol monomer-induced changes to the human faecal microflora. $\mathrm{Br}$ J Nutr 99, 782-792.

13. Sánchez-Patán F, Cueva C, Monagas M, et al. (2012) In vitro fermentation of a red wine extract by human gut microbiota: changes in microbial groups and formation of phenolic metabolites. I Agric Food Chem 60, 2136-2147.

14. Bialonska D, Ramnani P, Kasimsetty SG, et al. (2010) The influence of pomegranate by-product and punicalagins on selected groups of human intestinal microbiota. Int J Food Microbiol 140, 175-182.

15. Hidalgo M, Oruna-Concha MJ, Kolida S, et al. (2012) Metabolism of anthocyanins by human gut microflora and their influence on gut bacterial growth. J Agric Food Chem 60, 3882-3890.

16. Yamakoshi J, Tokutake S, Kikuchi M, et al. (2001) Effect of proanthocyanidin-rich extract from grape seeds on human fecal flora and fecal odor. Microb Ecol Health Dis 13, 25-31.

17. Cueva C, Sánchez-Patán F, Monagas M, et al. (2013) In vitro fermentation of grape seed flavan-3-ol fractions by human faecal microbiota: changes in microbial groups and phenolic metabolites. FEMS Microbiol Ecol 83, 792-805.

18. Costabile A, Klinder A, Fava F, et al. (2008) Whole-grain wheat breakfast cereal has a prebiotic effect on the human gut microbiota: a double-blind, placebo-controlled, crossover study. Br J Nutr 99, 110-120.

19. Costabile A, Kolida S, Klinder A, et al. (2010) A double-blind, placebo-controlled, cross-over study to establish the bifidogenic effect of a very-long-chain inulin extracted from globe artichoke (Cynara scolymus) in healthy human subjects. Br J Nutr 104, 10071017.

20. Kleessen B, Schwarz S, Boehm A, et al. (2007) Jerusalem artichoke and chicory inulin in bakery products affect faecal microbiota of healthy volunteers. Br J Nutr 98, 540-549.

21. Ramnani P, Gaudier E, Bingham M, et al. (2010) Prebiotic effect of fruit and vegetable shots containing Jerusalem artichoke inulin: a human intervention study. Br J Nutr 104, 233-240.

22. Carvalho-Wells AL, Helmolz K, Nodet C, et al. (2010) Determination of the in vivo prebiotic potential of a maize-based whole grain breakfast cereal: a human feeding study. $\mathrm{Br} J$ Nutr 104, 1353-1356.

23. Beards E, Tuohy K \& Gibson G (2010) A human volunteer study to assess the impact of confectionery sweeteners on the gut microbiota composition. Br J Nutr 104, 701-708.

24. Damen B, Cloetens L, Broekaert W, et al. (2012) Consumption of breads containing in situ-produced arabinoxylan oligosaccharides alters gastrointestinal effects in healthy volunteers. J Nutr 142, 470-477.

25. Walton G, Lu C, Trogh I, et al. (2012) A randomised, double-blind, placebo controlled cross-over study to determine the gastrointestinal effects of consumption of arabinoxylan-oligosaccharides enriched bread in healthy volunteers. Nutr J 11, 36.

26. Tzounis X, Rodriguez-Mateos A, Vulevic J, et al. (2011) Prebiotic evaluation of cocoa-derived flavanols in healthy humans by using a randomized, controlled, double-blind, crossover intervention study. Am J Clin Nutr 93, 62-72.

27. Vendrame S, Guglielmetti S, Riso P, et al. (2011) Six-week consumption of a wild blueberry powder drink increases bifidobacteria in the human gut. J Agric Food Chem 59, 12815-12820.

28. Queipo-Ortuño MI, Boto-Ordóñez M, Murri M, et al. (2012) Influence of red wine polyphenols and ethanol on the gut microbiota ecology and biochemical biomarkers. Am J Clin Nutr 95, 1323-1334.

29. Shinohara K, Ohashi Y, Kawasumi K, et al. (2010) Effect of apple intake on fecal microbiota and metabolites in humans. Anaerobe 16, $510-515$. 
30. Eid N, Walton G, Costabile A, et al. (2013) Polyphenols, glucosinolates, dietary fibre and colon cancer: understanding the potential of specific types of fruit and vegetables to reduce bowel cancer progression. Nutr Aging 2, 45-67.

31. Hong YJ, Tomas-Barberan FA, Kader AA, et al. (2006) The flavonoid glycosides and procyanidin composition of Deglet Noor dates (Phoenix dactylifera). J Agric Food Chem 54, 2405-2411.

32. El-Sohaimy SA \& Hafez EE (2010) Biochemical and nutritional characterizations of date palm fruits (Phoenix dactylifera L.). J Appl Sci Res 6, 1060-1067.

33. Eid NMS, Al-Awadi B, Vauzour D, et al. (2013) Effect of cultivar type and ripening on the polyphenol content of date palm fruit. J Agric Food Chem 61, 2453-2460.

34. Baliga MS, Baliga BRV, Kandathil SM, et al. (2011) A review of the chemistry and pharmacology of the date fruits (Phoenix dactylifera L.). Food Res Int 44, 1812-1822.

35. Zhang C-R, Aldosari SA, Vidyasagar PSPV, et al. (2013) Antioxidant and anti-inflammatory assays confirm bioactive compounds in Ajwa date fruit. J Agric Food Chem 61, 5834-5840.

36. Kuhnle G, Spencer JPE, Schroeter H, et al. (2000) Epicatechin and catechin are $O$-methylated and glucuronidated in the small intestine. Biochem Biophys Res Commun 277, 507-512.

37. Del Rio D, Rodriguez-Mateos A, Spencer JP, et al. (2013) Dietary (poly)phenolics in human health: structures, bioavailability, and evidence of protective effects against chronic diseases. Antiox Redox Signal 18, 1818-1892.

38. Tomás-Barberán FA, Martos I, Ferreres F, et al. (2001) HPLC flavonoid profiles as markers for the botanical origin of European unifloral honeys. J Sci Food Agric 81, 485-496.

39. Benedict SR (1909) A reagent for the detection of reducing sugars. J Biol Chem 5, 485-487.

40. Daims H, Stoecker K \& Wagner M (2005) Fluorescence in situ hybridisation for the detection of prokaryotes, pp. 213-240. In Molecular Microbial Ecology [AM Osborn and CJ Smith, editors]. New York and Abingdon: Taylor and Francis.

41. Langendijk PS, Schut F, Jansen GJ, et al. (1995) Quantitative fluorescence in situ hybridization of Bifidobacterium spp. with genusspecific 16S rRNA-targeted probes and its application in fecal samples. Appl Environ Microbiol 61, 3069-3075.

42. Harmsen HJM, Elfferich P, Schut F, et al. (1999) A $16 \mathrm{~S}$ rRNA-targeted probe for detection of lactobacilli and enterococci in faecal samples by fluorescent in situ hybridization. Microb Ecol Health Dis 11, 3-12.

43. Harmsen HJM, Wildeboer-Veloo ACM, Grijpstra J, et al. (2000) Development of 16S rRNA-based probes for the Coriobacterium group and the Atopobium cluster and their application for enumeration of Coriobacteriaceae in human feces from volunteers of different age groups. Appl Environ Microbiol 66, 4523-4527.

44. Lay C, Rigottier-Gois L, Holmstrøm K, et al. (2005) Colonic microbiota signatures across five northern European countries. Appl Environ Microbiol 71, 4153-4155.

45. Franks AH, Harmsen HJM, Raangs GC, et al. (1998) Variations of bacterial populations in human feces measured by fluorescent in situ hybridization with group-specific $16 \mathrm{~S}$ rRNA-targeted oligonucleotide probes. Appl Environ Microbiol 64, 3336-3345.

46. Daims H, Brühl A, Amann R, et al. (1999) The domain-specific probe EUB338 is insufficient for the detection of all bacteria: development and evaluation of a more comprehensive probe set. Syst Appl Microbiol 22, 434-444.

47. Gibson GR \& Roberfroid MB (1995) Dietary modulation of the human colonic microbiota: introducing the concept of prebiotics. J Nutr 125, 1401-1412.
48. Kemperman RA, Bolca S, Roger LC, et al. (2010) Novel approaches for analysing gut microbes and dietary polyphenols: challenges and opportunities. Microbiology 156, 3224-3231.

49. Altonsy MO, Andrews SC \& Tuohy KM (2010) Differential induction of apoptosis in human colonic carcinoma cells (Caco-2) by Atopobium, and commensal, probiotic and enteropathogenic bacteria: mediation by the mitochondrial pathway. Int J Food Microbiol 137, 190-203

50. Weaver GA, Krause JA, Miller TL, et al. (1988) Short chain fatty acid distributions of enema samples from a sigmoidoscopy population: an association of high acetate and low butyrate ratios with adenomatous polyps and colon cancer. Gut 29, 1539-1543.

51. Simpson EJ, Chapman MAS, Dawson J, et al. (2000) In vivo measurement of colonic butyrate metabolism in patients with quiescent ulcerative colitis. Gut 46, 73-77.

52. Zhang Y, Zhou L, Bao YL, et al. (2010) Butyrate induces cell apoptosis through activation of JNK MAP kinase pathway in human colon cancer RKO cells. Chem Biol Interact 185, 174-181.

53. Rowland IR, Rumney CJ, Coutts JT, et al. (1998) Effect of Bifidobacterium longum and inulin on gut bacterial metabolism and carcinogen-induced aberrant crypt foci in rats. Carcinogenesis 19, 281-285.

54. Costabile A, Fava F, Röytiö H, et al. (2012) Impact of polydextrose on the faecal microbiota: a double-blind, crossover, placebo-controlled feeding study in healthy human subjects. Br J Nutr 108, 471-481.

55. Tuohy KM, Conterno L, Gasperotti M, et al. (2012) Up-regulating the human intestinal microbiome using whole plant foods, polyphenols, and/or fiber. I Agric Food Chem 60, 8776-8782.

56. Spencer JPE (2003) Metabolism of tea flavonoids in the gastrointestinal tract. J Nutr 133, 3255S-3261S.

57. Selma MaV, Espín JC \& Tomás-Barberán FA (2009) Interaction between phenolics and gut microbiota: role in human health. J Agric Food Chem 57, 6485-6501.

58. Keppler K \& Humpf H-U (2005) Metabolism of anthocyanins and their phenolic degradation products by the intestinal microflora. Bioorg Med Chem 13, 5195-5205.

59. Fleschhut J, Kratzer F, Rechkemmer G, et al. (2005) Stability and biotransformation of various dietary anthocyanins in vitro. Eur $J$ Nutr 45, 7-18.

60. Nichenametla SN, Taruscio TG, Barney DL, et al. (2006) A review of the effects and mechanisms of polyphenolics in cancer. Crit Rev Food Sci Nutr 46, 161-183.

61. Nyangale EP, Mottram DS \& Gibson GR (2012) Gut microbial activity, implications for health and disease: the potential role of metabolite analysis. J Proteome Res 11, 5573-5585.

62. Mariadason JM, Velcich A, Wilson AJ, et al. (2001) Resistance to butyrate-induced cell differentiation and apoptosis during spontaneous Caco-2 cell differentiation. Gastroenterology 120, 889-899.

63. Bingham SA, Day NE, Luben R, et al. (2003) Dietary fibre in food and protection against colorectal cancer in the European Prospective Investigation into Cancer and Nutrition (EPIC): an observational study. Lancet 361, 1496-1501.

64. Terry P, Giovannucci E, Michels KB, et al. (2001) Fruit, vegetables, dietary fiber, and risk of colorectal cancer. J Natl Cancer Inst 93, 525-533.

65. Corona G, Deiana M, Incani A, et al. (2007) Inhibition of $\mathrm{p} 38$ / CREB phosphorylation and COX-2 expression by olive oil polyphenols underlies their anti-proliferative effects. Biochem Biophys Res Commun 362, 606-611.

66. Deiana M, Corona G, Incani A, et al. (2010) Protective effect of simple phenols from extravirgin olive oil against lipid peroxidation in intestinal Caco-2 cells. Food Chem Toxicol 48, 3008-3016 